\title{
Translation of crisis banking term system from English into Russian
}

\author{
Irina Zhirova ${ }^{1, *}$, Dmitriy Lukin $^{1}$, Maria Guseinova ${ }^{1}$, Olga Dmitrieva $^{1}$ \\ ${ }^{1}$ Moscow Region State University, 10A, Radio str., 105005, Moscow, Russia
}

\begin{abstract}
The article presents the consideration of the issues of semantics and pragmatics of crisis banking term system and its translation from English into Russian. The study of crisis banking term system is instigated due to the lack of linguistic works on the comparative analysis of semantic and pragmatic features of the crisis banking vocabulary presented in English and Russian. It has been established that the financial and economic crisis largely predetermined the formation of new terminological units that significantly supplemented the banking term systems of the English and Russian languages. It has been revealed that most of the new terms refer to the newly introduced anti-crisis vocabulary, along with lexemes that denote financial banking technologies aimed at improving the services provided by banks. Moreover, it has been particularly noted that the considerable part of the newly formed terms is obtained as a result of violation of the language norm of the English language, with consequent changes of the meaning, which is observed in the process of translation of the term into Russian. The article provides examples of the "shifts of meanings" in the English and Russian languages that are analyzed and explained. According to the results of the study, it could be stated that, in both English and Russian terminological units, there is a semantic unity, since the lexemic parts of the terminological phrases of the English language are semantically accurately translated into the Russian language.
\end{abstract}

\section{Introduction}

The material of the study is the crisis banking term system of the English language of 2008 and its translation into Russian. Globalization has strengthened the position of the English language, including the field of banking term system. Since a language is a method of forming and distributing information, any term system certainly reflects the correlation between the language and the professional community that uses this system. The term, which is a specialized word in the lexical-semantic system of any language, figuratively referred to as "a piece of reality" by Vinogradova V.V. [1], contains certain semantic and pragmatic information of social, political and cultural nature [2]. In the present case, such a fragment of reality is a unique financial and economic event occurred a little more than a decade ago, at the beginning of the XXI century - the global financial crisis of 2008 that

\footnotetext{
* Corresponding author: taniasemina@gmail.com
} 
quite heavily influenced the formation, development and functioning of the new banking terminology. The rapid update of the banking term system in this period of time is characterized by both the spontaneity of term-forming processes and the completely conscious influence of specialists in the banking field of the economy on the language and the formation of updated semantics of many terminological units.

It is natural that such a global socio-economic event affected the term system of both the English and other languages, including Russian. The influence of the English banking vocabulary has led to considerable changes in the semantic structures of the Russian term system. The economic crisis instigated a term-formation burst in the banking field. It is evident that during that period of time, a new, relatively independent terminological metalinguistic system was developed, constituting the global financial and economic communicative space. Moreover, the corpus of banking terms reflects the fundamental principles of integrity and functionality of the entire linguistic lexical-semantic system. The modern development of the worldwide banking vocabulary is largely determined by extralinguistic factors [3]. The external stimulus for the formation of the "new" financial language was the powerful financial crisis of 2008, which began in the United States of America with the mortgage crisis of 2006, and profoundly affected the entire world financial system about two years later. Most countries still feel the repercussions of the crisis [4].

Taking into account the fact that the banking term system undoubtedly serves as a "mirror" that reflects the socio-economic history of the world, the financial culture of cooperation between people living in the same country as well as between different nations, the financial and economic sector in general and professional banking terminology in particular are constantly affected by external factors [5]. In the process of studying the banking term system, a significant function is performed by such extralinguistic factors as: a) features of the formation and development of the relevant field of knowledge; b) the time and place of a socio-economic event; c) the current state of the industry both in the global world and in different countries; d) regional distinctions in the development of the financial and economic industry; e) conditions for the cooperation between nations in the global banking sphere.

Furthermore, the linguistic semantic and pragmatic aspect of the research of banking term system allowed establishing the following: a) the increase in the frequency of use of certain terms; b) the transformation of certain terms into key, dominant lexemes; c) a change of the axiological perception of certain terminological units; d) the conscious borrowing and calque of many lexical-semantic units from English to Russian. The semantics of a banking term indicates a number of key extralinguistic phenomena, such as: a) the globalization of banking services; b) increasing demand for banking services among the population and the level of competition between banks; c) regional infrastructure of the banking industry; d) government regulation and the social aspect; e) digitalization of almost all banking services. It is important to take into account the role of the mass media, which actively participate in the competition between many national bank corporations, that determinedly promote politicians to key government positions in different countries [6].

Thus, the object of the study is the crisis banking term system of 2008, the subject of the research is semantics and pragmatics in translation of crisis banking vocabulary from English into Russian, and the purpose of the article is to develop and describe theoretical and principles of communicative-information approach to the study of semantics and pragmatics, contained in a term, as well as to establish the degree of influence of the extralinguistic factor on the banking vocabulary, if it is possible. 


\section{Materials and methods of the study}

In order to conduct a comprehensive study of the crisis banking vocabulary as part of professional banking discourse and to ensure the significance of the study, a fragment of the extensive lexical material of the banking term system, which became the most relevant in 2008, has been involved in the analysis. The dynamic changes in the banking term system during the financial and economic crisis could be considered to be the major factor in the independence of the banking terminology as a whole. The crisis contributed to the qualitative update of the term system rather than the quantitative one.

The methodological basis of the study is the works of scientists in interdisciplinary area of scientific knowledge, which present the examination of the semantic and pragmatic features of a particular term (Zasurskiy, 2001; Petov, 2015; Heit, 2010; Nicholson, 2010; Mitchell, 2010; Lapata, 2010; Nosek, 2011; Graham, 2011; Hawkins, 2015). The study of crisis banking vocabulary allows to establish the accuracy of the transferred information through its narrowing/widening in semantics of a crisis banking term. In addition, the functional analysis of the studied terminological units makes it possible to discover their pragmatic component, which focuses on the sociolinguistic and linguoculturological features of communication in the field of professional banking. The main focus is on the functional and communicative aspects of the terminology [7].

The analysis of the collected material was based on general and specific methods of linguistic research, which allow to draw on strict facts and procedures, as well as to apply a more subjective approach to the organization of scientific research. Thus, in the process of collection and primary analysis of the materials the descriptive-analytical method was applied, which allowed to present the semantic and pragmatic features of the terms of the world banking crisis using the linguistic terminological tools [8]. Certainly, an important role in the study of the semantics of the crisis banking lexical system was played by the analysis of a dictionary definition, which revealed the components of meaning [9], as well as established their notional equivalents in two compared languages: English and Russian. Further involvement in the study of communicative research methods (information, contextual and interpretive analysis, in particular) allowed to present the law of functioning of such vocabulary in banking communication. The emergence of new banking services played a key role in the systemic and structural complication of the banking term system.

\section{Results}

It is established that the financial and economic crisis as an extralinguistic factor of extralinguistic reality predetermined the update of semantics of outdated terminological units and the formation of the new ones that substantially supplemented the English and Russian banking language with the terms of anti-crisis measures, new banking activities, as well as the innovative financial banking technologies aimed at improving the services provided by banks. The external impact on the vocabulary of banking terminology is systemic and conscious, since the specialized vocabulary is associated with intellectual (analytical) rather than emotional thinking. It is evident that, during the financial and economic crisis, the banking terminology was subjected to completely conscious, socially and culturally-based influence on the part of banking analysts who have carried out the necessary reforms in the economic area. The imbalance of the external factors predetermined the extraordinary intervention in the language system, which was unstable during the crisis. The restructuring of the banking term system was required to simplify interlingual communication in the economic sector. 
Taking into account the strengthening positions of developed and developing economies in a number of countries, it has become obvious that it is necessary to develop and conduct a comprehensive analysis of terminological units that directly reflect global (transnational) changes in the world banking sphere. Thus, in order to achieve the successful functioning of industry-specific institutions of banking regulation, it is important to take into account both internal and external extralinguistic factors that affect the structure of economies. More specifically, despite the fact that a number of countries do not welcome the interference in their financial and economic activity, in the context of international trade the "isolationism" has an extremely negative effect not only on the purely economic, but also on the intercultural dialogue of various countries and communities. The incorporation of terminological units in the time of global economic changes in the intercultural space is the key to a pragmatic approach to solving the most significant problems of the world community which is the ability to conduct not only political, but also linguocultural dialogue within the new emerging geoeconomcs. Under these circumstances, the positions of those researchers of banking terminology who propose to maximize the consolidation of information flows in the banking sphere through the banking term system seem reasonable. The importance of this strategy is determined on the one hand, by the diversity and heterogeneity of term systems in different countries, as well as socio-cultural factors that influence the distribution of certain lexical units as part of a system analysis of the development of the global economy situation, on the other hand.

It is revealed that the global consolidation and transnationalization of the financial sector of the global economy predetermined the functioning of banking terminological units within one industrial (financial and economic) term system. In addition, the banking term system is extremely informative in the global information and communicative space. The "global" banking term, formed during the financial and economic crisis, indicates a significant level of development of the entire world banking industry. It is established that the banking term is characterized by multiple elements, which allows to term a complex banking concept. The emergence of new meanings in the banking vocabulary has led to the polysemy of many terminological units, which indicates the global terminologisation of the banking terminology occurred due to sociolinguistic and linguoculturological processes.

It should be noted that these processes are progressive, owing to the distinctions in the interpretation of terms that differ from each other due to the specifics of the operation of international financial corporations. Such a postulate does not understate the importance of terminology databases in languages as one of the indicators of successful functioning of lexical units in the intercultural space. Cross-cultural analysis of certain words and phrases allows not only to adapt a foreign lexeme taking into account the norms of the source language, but also to take a slightly different look at the problem of word-by-word translation of the original units into Russian. During the comparison linguistic units, it becomes possible to update cultural dominant ideas, which appear to be on the periphery of the interlingual dialogue, however, often require the increased attention due to the language specificity. Thus, dictionary definitions could undergo significant changes in the translation process, that are determined not only by global terminological shifts during the economic crisis, but also by the direct influence of another language culture.

\section{Discussion}

In the process of the study of the financial and economic crisis, it was noted that it enriched the banking vocabulary with new terms, as well as built awareness of the terminological units that were not frequently applied in the pre-crisis period. The terms "credit default 
swap"/ кредитный дефолтный своп, "mortgage" / ипотека, закладная could serve as an example. Due to the need to describe crisis events as quickly as possible, all countries have adopted the American terminology. Borrowing the English term in the translation into Russian is widely used in relation to financial terms, especially derivatives and crisis terminology. In Russia, financial managers and investors use English terms when discussing issues with Russian-speaking colleagues, since in some cases Russian equivalents are less accurate and less familiar to financial professionals. The crisis of 2008 was also called "subprime mortgage crisis" and the "subprime mortgage" term, previously known only in narrow circles, started to be used by all world mass media.

The increase of a 'subprime mortgage' distribution has led to a real estate bubble in the US. The term has obtained a negative connotation and a factor in the development of an unfavorable economic environment. The large loan was granted to the borrowers with an unreliable and little credit history without proper test of their solvency. In Russian banking, the mortgage market was at the stage of its formation. Therefore, the use of complex tools, such as subprime mortgages, did not enter Russia. Thus, Russian specialists managed to take into account the world's experience and eliminate the crisis in the real estate market of 2008 in the country.

A key phenomenon in the banking terminology was the update of the dictionary of financial and economic terms, IMF Glossary WEB - 1988 April 2013 - (English Russian French). The development of a large multi-purpose dictionary of such terms has resonated with the International Monetary Fund, which introduced additional terminological phrases in the dictionary during the global economic crisis. For instance, the new terminological unit "balance sheet approach to financial crisis" is translated into Russian as "подход к анализу финансового кризиса на основе баланса".

1) In adapting to their new operating landscape, banks have been re-assessing and adjusting their business strategies and models, including their balance sheet structure, cost base, scope of activities and geographic presence [10].

2) Анализ финансового состояния - один из важнейших этапов оценки результатов, достигнутых банком по итогам отчётного года. На основе данных такого анализа собственники и менеджмент получают информацию о факторах, повлиявших на результать бизнеса, оченивают экономические возможности по дальнейшему развитию [11].

In the Russian translation, there is a semantic widening of the term: the lexemes are added that are not present in the English phrase, namely, анализ, на основе. Moreover, the English term balance sheet was subjected to semantic reduction in Russian, since in such cases the Russian language traditionally seeks to save language means. It is quite evident that the multi-element (a word-combination) English terminological unit "balance sheet approach to financial crisis" involves the two most important types of semantic relationships: the object and subject ones. Thus, the object relationships indicate the connection of the abstract object of the analysis, "balance sheet approach", to the extralinguistic reality, "financial crisis". Furthermore, approach and crisis are the objects, and balance sheet and financial are their attributes. The subject relationship of these terminological phrases conveys information on the way the thinking qualifies the object relationships established between the elements of the terminological units. So, from the semantic perspective, the subject relationship in "balance sheet approach" is expressed by the "noun + noun + noun" structure, while in "financial crisis" it is represented by the link "adjective + noun" combination. Subtle semantic differences are observed between these two ways of expressing attributive semantics. In the first phrase, the subject-attributive characteristic of the object is updated, and in the second phrase, the update concerns the self-attributive characteristic. In the Russian compound term "подход $к$ анализу 
финансового кризиса на основе баланса", the key role is played by the structural relationship between the elements of the extralinguistic reality, which forms a diffuse, ambiguous semantic interdependence of all elements. This relationship, which is peculiar to the Russian language, leads to a formal increase in the lexical volume of the syntactic construction of the terminological unit. This phrase formalized as a term in the Russian language involves a domination (coordination, government, etc.) structural connection of semantic relationships between its elements. Thus, the main objective is to establish a standard functional semantics, aimed to transfer the description of almost all components of the analyzed terminological unit from its grammatical semantics to the syntactic one. Therefore, the structural connection between the elements of the phrase becomes systemintegrating. Certainly, the information contained in the English terminological unit is transferred to the Russian language, primarily taking into account the syntactics. In a Russian terminological phrase, the subject relationship ("adjective + noun") is present only in one element, "финансовый кризис".

The English language is extremely flexible: currently, there is a process of violation of many language norms of the use of many words and phrases. It is revealed that one of the most common techniques is a change in the lexeme's meanings. Shifts in the meanings of existing words are either widening or narrowing. The quantitative (percentage) ratio of shifts in the meanings of English and Russian banking terms is depicted in Figure 1.
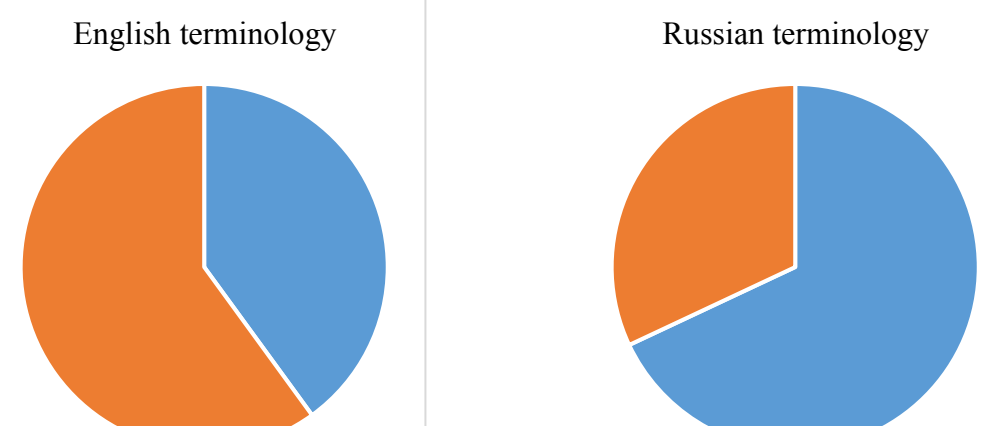

Fig. 1. Quantitative ratio of shifts in the meanings of banking terminology in the English and Russian languages.

Such processes lead to the formation of the new semantic connotations in the meanings of words, to their polysemy, which should be regarded as a feature of functioning of the English language [12].

During the financial and economic crisis, the international fund introduced certain notions for developing countries such as adjustment (of quotas) / изменение квот, adjustment (program) / программа стабилизации, etc into the banking term system. For instance:

1) This adjustment has occurred mainly through a reduction in business volumes rather than the exit of firms from the market [13].

2) Россия может поднять вопрос об изменении ее квоты, установленной в соглашении стран ОПЕК и не-ОПЕК об ограничении добычи нефти, на встрече стран - участнии этого соглашения [14].

In English, there is a semantic broadening of meaning of the noun adjustment. The original meanings of the commonly applied lexeme "adjustment: means of setting right, putting in order, regulating, making suitable or convenient for use" [15], were widened with the new, more specific meanings "changing" and "stabilize / consolidate" in the 
banking term system. When analyzing the terminological meanings of the adjustment lexeme, it becomes evident that the word is semantically wide, since it contains the basic information on the message expressed, however, its use in the text leads to a natural narrowing of the content. In the Russian language, the content of the financial-economic term is correlated with the content of the English term.

Due to the global financial crisis, there was an emergence of the key phrase: global savings glut/ глобальный избыток сбережений in the English and Russian banking term systems.

1) To be more specific, I will argue that over the past decade a combination of diverse forces has created a significant increase in the global supply of saving--a global saving glut--which helps to explain both the increase in the U.S. current account deficit and the relatively low level of long-term real interest rates in the world today [16].

2) Общая ошибка заключается в том, что глобальный избыток сбережений приписывается желанию развивающихся стран застраховать себя от финансовой паники путём сбора долларовых резервов [17].

Thus, the comparative analysis of the semantics of the English and Russian terminological units indicates that the calque method with a change in the word order in the Russian variant was applied in translation of the terminological phrase from English into Russian. The key element in the term unit global savings glut is the glut lexeme, which has the synonym surplus in the English common language. Both units denote "излишек, избыток" (excess) in the Russian language. In the explanatory dictionary of Hornby A.S. "OALDofCE" glut is "supply in excess of demand" [18], while surplus is "amount of anything in excess of requirements" [18]. However, in the English language, in the formation of the terminological unit, the preference is given to the shorter "glut" lexeme. The term system of the English language contains both terminological units, the meanings of which are significantly different. Thus, glut has the meaning of "more of something than is needed" [19], which corresponds to the Russian "избыток; закупка; затоваривание; перенасыщение рынка товарами или определёнными финансово-банковскими инструментами, ведущее к существенному снижению цен" [20]. While surplus has two meanings indicating their significant semantic terminological distinction: "a) excess of assets over the paid-up capital; b) positive balance; excess of expenses over income" [20]. The key role in the formation of the polysemy of a terminological unit is played by the social conditioning and linguistic culture of social relations that have developed in the American society.

The financial market risks, peculiar to the world economic crisis, has led to the adoption of the US Federal Reserve System, a large-scale program of "quantitative easing"/ количественного смягчения, the reasonable purpose of which is to restore the production in the USA as quickly as possible. The policy of "quantitative easing"/ количественного смягчения has been negatively responded in the financial-economic circles of many countries. Thus, Anthony Randazzo points out that the "quantitative easing is a fancy term for the Federal Reserve $<\ldots>$. It is a primary driver of income inequality formed by crony capitalism. And it is hurting prospects for economic growth down the road by promoting malinvestments in the economy." [21]. While Donald Trump expressed a positive opinion on the program: "People like me will benefit from this" [22].

The policy of "quantitative easing" is usually carried out in the countries where the interest rate is very low and the further reduction is not possible. The key driver of the policy is the purchase of securities by the state, which indirectly reduces the interest rate. This leads to the loan growth that accelerates the economic advance. According to the experts, the policy of quantitative easing in the United States had a positive impact on the economic growth, the unemployment rate and the financial stability. 
In the English terminological unit quantitative easing, quantitative serves as an attributive lexeme, which is characterized by the broadened semantics: the notion of "quantitative" is explicitly present in the terminological unit, while the other concept ("the issued money") is implicit. The easing lexeme, that denotes "easing pressure on banks", appeared in the banking term system in 2000. The Central Bank of Japan introduced the term to denote stimulation of the economy. The term is translated into Russian through the application of loan translation with a completely borrowed meaning from English. In addition, thereafter, the lexeme "easing" broadened its meaning and began to be applied not only in the context of the monetary policy, but also in relation to the sanctions that were imposed on Russia by the United States and the Eurozone in 2012-2014.

1) As the COVID-19 pandemic progresses, the UNHigh Commissioner for Human Rights on Tuesday called for an easing of sanctions against countries such as Iran to allow their medical systems to fight the disease and limit its global spread [23].

2) Недавно агентство улучшило прогноз по рейтингу России до стабильного, но в отношении санкций настроение специалистов не столь оптимистично. Международное рейтинговое агентство $S \& P$ не ожидает ослабления санкиионного режима в отношении России в ближайшее время, заявил директор направления "суверенные рейтинги" агентства Рави Бхатия [24].

Any crisis also changes the attitude of market participants towards risks, and the crisis of 2008 was no exception. New tools applied for the control over financial risks instigate the transformation of the major concepts into the new terms. The use of the term "ringfencing", which denotes the division of the banking business into basic bank services (deposits, loans, etc.) and the investment department, which protects the bank's customers from bankruptcy of the investment department, could serve as an example. In addition to the emergence of the new noun "ring-fencing", meaning "ограждение/выделение", the verb derived from the above-mentioned noun "to ringfence" has also begun to be applied. This verb is translated into Russian as "оградить/выделить". The English term "ringfencing" was not borrowed into the Russian language since this reform was not needed in Russia [25]. At the time of the crisis, the Russian investment business was at the initial stage of development, therefore, the translation and borrowing of this term was not required. Furthermore, most financial institutions have taken into account the repercussions of the 2008 crisis, and the investment services in Russia are most commonly separated from classical banking services: Sberbank and Sberbank CIB, VTB and VTB Capital, etc. [26].

The crisis of 2008 inspired investors to use new terms to describe the types of a bank resolution: "bail in" (bank resolution at the expense of the creditors) and "bail out" (bank resolution at the expense of the state). In Europe and the United States, a mechanism for both bank resolution types and the term base have been developed. The term "bail out" (bank resolution at the expense of the state) is applied in most countries, however, "bail in" (bank resolution at the expense of the creditors) is practically applied in Cyprus and Portugal. In Russia, the term "bail in" has not been used, partially because the regulatory framework does not include the bank resolution at the expense of creditors. Since there is no need for application of the terms "bail in" (bank resolution at the expense of the creditors) and "bail out" (bank resolution at the expense of the state) in Russia, the method of replacing the term with a more accurate and succinct analogue is used in the translation of the terms concerning bank resolution [27].

In conclusion, it should be noted that, in the financial-economic terminology, there is an apparent semantic, informational evolution of a terminological unit. Moreover, there is an emergence of new objectives for translators, who, owing to multi-element terminological units, would be able to much more widely use various translation strategies and tactics 
when transferring the semantic content of different terms. The advance in the development of modern terminology studies is the global unification of meanings of terms in different languages, which would undoubtedly lead to the stability of meanings as well as the form of terminological lexical units. The "internationality" of meanings would contribute to the dedication of all members of a professional community to the more effective communication.

\section{Conclusion}

Thus, the global financial crisis has been a source of enrichment and transformation of the banking term system of the English language, which contributed to the formation of the Russian banking system. The comparative analysis of the two systems indicates a universal nationally-determined specificity of the transfer of semantic and pragmatic features of banking terms: the calque translation with narrowing or widening of the semantic content of a terminological unit in the Russian language.

Due to the 2008 crisis, many English terms, which had been applied only by financial industry experts, became widely used. Like many other crises, it has expanded the vocabulary of each person and introduced the words such as: "CDS", "ring-fencing" and "mortgage". Every financial crisis thereafter would expand the lexical structure of the term system and generate new financial terms and phrases.

The analysis of the transformation of the banking term system of the Russian language allows to discover that it is almost completely dependent on the banking term system of the English language and derived from it. By drawing an analogy with financial markets, it is possible to compare the banking term system of the English language with the underlying (for instance, oil or gold), and the banking term system of the Russian language with the derivative (for example, oil or gold futures). The nature of this dependence lies in the establishment of the global economic system based on the Anglo-Saxon economic model, which dictates the trend in financial markets since the Age of Discovery, as well as in the strengthening of tendency towards globalization.

Moreover, it could be noted that in both English and Russian terminological units there is a semantic unity, since the lexemic parts of the terminological phrases of the English language are semantically accurately translated into the Russian language. It is quite natural that the banking term possesses a professional motivation, since it is characterized not only by accuracy and informativity, but also by the emotional neutrality, which is extremely necessary for a terminological unit. The major factor in the formation of the new banking term system is the increase in the semantic volume of existing terms, which naturally led to the emergence of new meanings, correlated both lexically and structurally. In addition, the comparative analysis of the English and Russian banking term systems allows to confirm the existence of strong system connections of the banking vocabulary of the two languages.

\section{References}

1. V.V. Vinogradov, Leksikologiya i leksikografiya. Izbrannyye trudy (M., Nauka, 1977)

2. C.J. Fillmore, Annals of the New York Academy of Sciences: Conference on the Origin and Development of Language and Speech New York 280, 20 (1976)

3. N. Atayeva, International Journal Of Scientific \& Technology Research 8(10), 1097 (2019)

4. P. Nomi, Collusion: How Central Bankers Rigged the World (Nation Books, 2018) 
5. P. Faber, A Cognitive Linguistics View of Terminology and Specialized Language (Berlin, Boston, De Gruyter Mouton, 2010)

6. V. Pakhomov, Kak otsenivayetsya reputatsiya i delovoy imidzh bankov (Moscow, 2002)

7. P. Faber, A Cognitive Linguistics View of Terminology and Specialized Language (Berlin, Boston, De Gruyter Mouton, 2010)

8. B.A. Nosek, J. Graham, C.B. Hawkins, Implicit political cognition. Handbook of Implicit Social Cognition: Measurement, Theory, and Applications (New York, The Guilford Press, 2010)

9. Ya.N. Zasurskiy, Sistema sredstv massovoy informatsii Rossii (Moscow, Aspekt press, 2001)

10. C. Buch, Structural changes in banking after the crisis Report. A report of a working Group established by the Committee on the Global Financial System (Federal Reserve Bank of New York, 2018)

11. PEO - Planovo Ekonomicheskiy otdel (Moscow, 2019) https://www.profiz.ru/peo/12_2019/finansovyj_analiz

12. A.A. Zaliznyak, Mnogoznachnost' v yazyke i sposoby yeye predstavleniya (Moscow, Izd-vo Yazyki slavyanskikh kul'tur, 2006)

13. C. Buch, Structural changes in banking after the crisis Report. A report of a working Group established by the Committee on the Global Financial System (Federal Reserve Bank of New York, 2018)

14. Rossiya dobivayetsya ot OPEK izmeneniya kvot na dobychu nefti (Vesti Moskva, 2019) https://www.vedomosti.ru/business/articles/2019/11/27/817351-rossiya-opek

15. A.S. Hornby, Oxford Advanced Learner`s Dictionary (Oxford University Press, 2004)

16. S. Bernanke, The Global Saving Glut and the U.S. Current Account Deficit (Richmond, Virginia, Virginia Association of Economists. Lecture, 2005) https://www.federalreserve.gov/boardDocs/Speeches/2005/200503102/

17. Stolknetsya li mirovaya ekonomika s dlitel'nym zastoyem (Vesti Moskva, 2020) https://www.vestifinance.ru/articles/56437

18. A.S. Hornby, Oxford Advanced Learner's Dictionary (Oxford University Press, 2020)

19. Cambridge Dictionary online, https://dictionary.cambridge.org

20. Cambridge English-Russian dictionary

https:/dictionary.cambridge.org/dictionary/english-russian/

21. V.Yu. Katasonov, Za kulisami mezhdunarodnykh finansov (Moscow, ID KISLOROD, 2015)

22. CNBC (2020) com. http://www.cnbc.com

23. Glava OON rasskazal o svoikh prioritetakh na 2020 god (Novosti OON, 2020) https://news.un.org/ru/story/2020/01/1371131 
24. V S\&P rasskazali o shansakh na oslableniye sanktsiy $v$ otnoshenii Rossii (RIA Novosti, 2016) https://ria.ru/20161101/1480425654.html?in=t

25. Ring-fencing. Financial Conduct Authority (UK, 2019) http:// https://www.fca.org.uk/consumers/ring-fencing

26. Kak izmenilis' riski za 10 let posle mirovogo krizisa (Vedomosti, 2018) https://www.vedomosti.ru/economics/articles/2018/09/13/780777-izmenilis-riski-10let-krizisa

27. Vkladchiki-spasiteli: kak rabotayet bail-in v SSHA i Yevrope (RBK Moskva, 2016) http: https://www.rbc.ru/finances/03/02/2016/56b1 fe649a794710e4abb537 